\title{
GROWTH AND SURVIVAL OF PINK SHRIMP (Farfantepenaeus paulensis) POSTLARVAE IN CAGES AND PEN ENCLOSURES
}

\author{
Luciano Jensen Vaz*; Wilson Wasielesky Jr.; Ronaldo Olivera Cavalli; Silvio Peixoto; Marcos \\ Henrique Silva Santos; Eduardo Ballester \\ Fundação Universidade Federal do Rio Grande - Depto. de Oceanografia - Lab. de Maricultura, C.P. 474 - \\ 96201-900 - Rio Grande, RS - Brasil. \\ *Corresponding author <jensenlv@yahoo.com.br>
}

\begin{abstract}
Technology for the culture of the pink shrimp Farfantepenaeus paulensis in low-cost cages and pen enclosures was developed together with artisanal fishermen of the Patos Lagoon estuary, southern Brazil. Although the production of postlarvae (PL) under laboratory conditions is well documented, survival and growth during the nursery phase cages and pen enclosures in the nature has not yet been analyzed. Therefore, the present study compared survival and growth of $F$. paulensis postlarvae reared either in cages or pens. Six cages $(2.0 \times 2.0 \times 1.4 \mathrm{~m})$ of PVC-coated polyester with a mesh size of $1.5 \mathrm{~mm}$ were stocked with $800 \mathrm{PL}_{26}$ each. To assess the effect of the substrate, a $10 \mathrm{~cm}$ layer of sand was added to three of these cages to simulate a pen enclosure. No difference in the mean survival rate between cages $(92.2 \%)$ and pens $(88.7 \%)$ was found $(P>0.05)$. However, final weight of shrimp reared in pens $(1.05 \pm 0.05 \mathrm{~g})$ was higher than those kept in cages $(0.88 \pm 0.12 \mathrm{~g})$. The nursery phase of $F$. paulensis in cages and pens did not affect survival. Nevertheless, because of the higher growth rate of shrimp grown in pen enclosures, this kind of structure should be preferentially used in nursery rearing of this species.
\end{abstract}

Key words: Penaeidae, aquaculture, shrimp farming, nursery

\section{CRESCIMENTO E SOBREVIVÊNCIA DE PÓS-LARVAS DE CAMARÃO-ROSA (Farfantepenaeus paulensis) EM GAIOLAS E CERCADOS}

\begin{abstract}
RESUMO: Um pacote tecnológico para o cultivo do camarão-rosa em estruturas alternativas de baixo custo, gaiolas e cercados, vem sendo aplicado em conjunto com pescadores artesanais do estuário da Lagoa dos Patos, no extremo sul do Brasil. Embora a tecnologia para o cultivo intensivo de pós-larvas (PL) em laboratório já esteja bem documentada, informações referentes à sobrevivência e crescimento desses organismos na fase de berçário ainda são escassas para cercados e gaiolas no ambiente natural. Em virtude destes fatos, o objetivo do trabalho foi comparar o crescimento e a sobrevivência de pós-larvas de $F$. paulensis durante a fase de berçário em gaiolas e cercados no ambiente. Para o desenvolvimento do trabalho, foram utilizadas seis gaiolas $(2,0 \times 2,0 \times 1,4 \mathrm{~m})$ com malha de poliéster revestida de PVC com abertura de malha de 1,5 mm. Em cada unidade foram estocadas $800 \mathrm{PL}_{26}$. Para verificar a influência do substrato, foram espalhados uniformemente $10 \mathrm{~cm}$ de sedimentos da própria enseada dentro de três gaiolas, simulando um cercado. A taxa de sobrevivência dos camarões obtida nas gaiolas foi de $92,2 \%$ e nos cercados de $88,7 \%$, não sendo detectadas diferenças $(P>0,05)$. Porém, o peso médio final dos camarões nos cercados $(1,05 \pm 0,05 \mathrm{~g})$, foi superior $(P<0,05)$ ao peso dos camarões nas gaiolas $(0,88 \pm 0,12 \mathrm{~g})$. A espécie pode ser cultivada na fase de berçário em gaiolas ou cercados sem prejuízo à sobrevivência final. Entretanto, recomenda-se que a fase de berçário seja realizada preferencialmente em cercados.

Palavras-chave: Penaeidae, aqüicultura, carcinicultura, berçário
\end{abstract}

\section{INTRODUCTION}

Shrimp culture has received a great deal of attention worldwide mainly because of the growing market demand and high commercial value attained by the product. In general, shrimp culture is conventionally carried out in tanks or ponds with relatively high production costs. On the other hand, in some Asian countries (Thai- land, Philippines, Singapore, and India) alternative culture methods, utilizing cages and pen enclosures, have been utilized (Peña \& Prospero, 1984). The application of these systems usually results in lower production costs, which allows lower economic income communities to culture shrimp (Walford \& Lam, 1987).

Although cages and pens are mainly used for culturing fish, many researchers are also investigating their

Sci. Agric. (Piracicaba, Braz.), v.61, n.3, p.332-335, May/June 2004 
use for shrimp culture in Brazil. Wasielesky et al. (1995) in Rio Grande do Sul, Paquotte et al. (1998) in Bahia, Scardua (1998) in Santa Catarina, and Ostrensky \& Pilchowski (2002) in Paraná, have considered culturing shrimp in cages and/or pens.

In the state of Rio Grande do Sul, many studies have been performed to determine the best conditions for the culture of the pink-shrimp Farfantepenaeus paulensis either under laboratory (Tsuzuki et al., 2000; Thompson et al., 2002) or natural environment conditions (Zogbi, 1997; Santos et al., 1999). All these studies indicated the high growth potential of this species. Although the technology for the production of post-larvae of the species in laboratory is well developed, there is still need for information on its culture in the nature, especially in relation to survival and growth of post-larvae during the nursery phase.

The nursery phase is an intermediate step between larviculture and grow-out, and is usually characterized by high stocking densities, high water renewal rates and feeding with top quality artificial diets (Speck et al., 1993). The main objective of the nursery phase is producing larger and sturdier juveniles, which will probably have a better chance of survival and may achieve commercial size in shorter time (Apud et al., 1983). For $F$. paulensis, the nursery phase usually begins when shrimps attain $0.06 \mathrm{~g}\left(\mathrm{PL}_{25}\right)$, and last until they reach over $0.36 \mathrm{~g}$ or $36 \mathrm{~mm}$ of total length (Dolci \& Wasielesky, 1998). These values were stipulated to avoid shrimp escaping through the mesh of the larger pen enclosures used to grow $F$. paulensis up to commercial size (Wasielesky, 2000).

The purpose of this work was to compare the survival and growth of $F$. paulensis post-larvae reared in cages or pens during the nursery phase in a natural environment. The percentile of the post-larvae population with weight over $0.36 \mathrm{~g}$ was also evaluated in order to define the best moment for transfering them to grow-out structures.

\section{MATERIAL AND METHODS}

The experiment was set up in Saco do Justino bay, a shallow estuarine inlet of the Patos Lagoon, Rio Grande, RS (32 03 ' S, 52 $\left.05^{\prime} \mathrm{W}\right)$, southern Brazil, during February and March 2001. The experimental period lasted 31 days. Six cages were divided in two treatments (cages and pens) with three replicates. Dimension of the cages was $2.0 \times 2.0 \times 1.4 \mathrm{~m}$ (length $\mathrm{x}$ width $\mathrm{x}$ height). Cages built with PVC-coated polyester $(1.5 \mathrm{~mm}$ mesh size) were supported by bamboo poles. Each unit had $4 \mathrm{~m}^{2}$ of bottom area and was stocked with $800 \mathrm{PL}_{26}$, which corresponded to a density of $200 \mathrm{PL} \mathrm{m}^{-2}$. To evaluate the influence of the substrate, three cages were evenly filled with a $10 \mathrm{~cm}$ sediment layer order to simulate the condi- tions of pens. The sediment was obtained from the same estuarine inlet. This procedure was used to facilitate the evaluation of the final survival, which could be more difficult if bottomless pens were used.

The post-larvae used in the experiment were cultured during 26 days $\left(\mathrm{PL}_{26}\right)$. At this age, they already acquired a higher tolerance to low salinity levels (Tsuzuki et al., 2000), which allowed them to be transferred to the experimental units after previous acclimatization. During the experimental period, post-larvae were fed twice a day, at $9 \mathrm{~h} 00$ with a commercial diet, and at $21 \mathrm{~h} 00$ with fresh minced crustaceans (crab and shrimp heads). Feed was provided in one feeding tray per experimental unit. Initial feeding rate was $50 \%$ of the total biomass and was periodically adjusted according to the amount of feed left in the trays.

Monitoring of growth was performed at days 1 , $14,22,26$, and 31 after stocking. One hundred shrimp from each experimental unit were randomly sampled, weighed (wet weight) and returned to the respective unit. At the end of the trial, the interval between successive growth measurements was gradually decreased to allow a closer growth monitoring as shrimp were reaching the target weight of $0.36 \mathrm{~g}$.

Water temperature $\left(0.5^{\circ} \mathrm{C}\right.$ precision thermometer $)$ and salinity (one unit precision optical refractometer) were measured daily. Water samples from each experimental unit and a control point placed $30 \mathrm{~m}$ away from the culture site were collected at morning (9h00) to measure dissolved oxygen (Strickland \& Parsons, 1972), pH (desktop pH meter), total ammonium (UNESCO, 1983) and nitrite concentrations (Benscheneider \& Robinson, 1952).

Final weight and number of shrimp of each replicate were submitted to analysis of variance (ANOVA), and if no differences were found $(P>0.05)$ results were pooled. The same procedures were used to determine differences between the abiotic data of the different treatments and the control point.

\section{RESULTS AND DISCUSSION}

Deterioration of water quality may cause stress to cultured organisms, negatively affecting growth and increasing their susceptibility to pathogenic agents that may cause mortality (Arulampalam et al., 1998). This is the reason why monitoring water quality is an indispensable procedure if the culture of any aquatic organisms is to be successful. In open culture systems, such as cages and pens, water minor quality problems may occur, but this will certainly depend on the water renewal rate of the place where the structures are installed.

In the present study, water temperature was 26.06 $\pm 1.56^{\circ} \mathrm{C}$ with minimum and maximum values ranging from 24.0 to $29.0^{\circ} \mathrm{C}$, while salinity ranged between 4.0 and $10.0 \%$, averaging $7.28 \pm 1.74 \%$. The mean con- 
centration of dissolved oxygen was $7.76( \pm 0.67) \mathrm{mg} \mathrm{L}^{-1}$ and $\mathrm{pH}$ was $8.58( \pm 0.14)$. Means $( \pm \mathrm{SD})$ of nitrite and total ammonium were $0.06 \pm 0.04 \mathrm{mg} \mathrm{L}^{-1}$ and $0.08 \pm$ $0.06 \mathrm{mg} \mathrm{L}^{-1}$, respectively. All measured water quality parameters were within the tolerance limits considered not to affect penaeid shrimp (Vinatea, 1997).

During the first 26 days, no differences in wet weight were found between treatments $(P>0.05)$. However, at the end of the trial, shrimp cultured in pens reached a higher weight $(1.05 \pm 0.05 \mathrm{~g})$ than those reared in cages $(0.88 \pm 0.12 \mathrm{~g})(P<0.05)$. Wasielesky (2000) cultured $F$. paulensis in cages and pens during 90 days in Patos Lagoon and found that the mean growth rate (g per week) was higher in pens $(0.56 \mathrm{~g})$ than in cages $(0.38 \mathrm{~g})$, which confirms the present results. Pen enclosures seem to allow better growth of $F$. paulensis probably because higher quantity and diversity of natural food items, especially benthic organisms, may be present in the sediment.

During the nursery phase, survival is considered a parameter of great importance in the success of any shrimp production operation. Ballester et al. (2001) investigated the role of biofilm (a community of autotrophic and heterotrophic microorganisms attached to submersed surfaces) on the survival and growth of $F$. paulensis in nursery systems in natural environment. These authors used stocking densities of 300 shrimp $\mathrm{m}^{-2}$ and obtained final survival rates between 96 and $99 \%$. Speck et al. (1993) reared $F$. paulensis post-larvae in an indoor nursery system at the densities of 150,300 and 600 shrimp $\mathrm{m}^{-2}$ and obtained survival rates of 85,84 and $16 \%$, respectively. $F$. paulensis juveniles were reared in the Patos Lagoon and mean survival values in cages and pens were 90 and 95\%, respectively (Wasielesky, 2000). In the present study, the type of structure had no influence on the survival rates of $F$. paulensis post-larvae (Table 1). During the experimental period, the percentile of the population reaching the target weight of $0.36 \mathrm{~g}$ was moni-

Table 1 - Mean $( \pm$ SD) final wet weight and survival of $F$. paulensis post-larvae reared during 31 days in cages or pen enclosures.

\begin{tabular}{|c|c|c|}
\hline Treatment & Final wet weight & Survival \\
\hline & 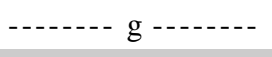 & $\ldots \ldots$ \\
\hline Pen enclosures & $1.05 \pm 0.05^{\mathrm{a}}$ & $88.7 \pm 2.8^{\mathrm{a}}$ \\
\hline Cages & $0.88 \pm 0.12^{\mathrm{b}}$ & $92.2 \pm 3.6^{\mathrm{a}}$ \\
\hline
\end{tabular}

Within each column, different letters means difference between treatments $(P<0.05)$. tored (Table 2), but no differences among treatments was recorded $(P>0.05)$.

Waiting for all the shrimp to achieve a weight over $0.36 \mathrm{~g}$ may not be an interesting strategy, because many individuals will have reached a much larger size by then. Therefore, it would be wiser to have them transferred to grow-out structures as soon as possible. The transference should not be retarded in order not to affect final production. It seems the time that when $95 \%$ of shrimp post-larvae reach over $0.36 \mathrm{~g}$ live weight would probably be the best moment to have them transferred to grow-out structures. This percentile was stipulated in function of the cannibalistic nature of this species, which could negatively influence not only the size uniformity of the lot, but also their survival rate.

\section{CONCLUSION}

F. paulensis may be cultured in cages or pens during the nursery phase with no losses in terms of survival. However, the use of pen enclosures during the nursery phase is recommended, especially when considering that the installation costs of pens are comparatively lower than cages, as less netting material is required per unit area. Therefore, starting from an economic point of view, the use of pen enclosures appears to be more attractive.

\section{ACKNOWLEDGMENTS}

To FAPERGS, Polo Pesqueiro (SCT-RS) and CAPES for partial support. W. Wasielesky and R.O. Cavalli are research fellows of CNPq.

\section{REFERENCES}

APUD, F.D.; PRIMAVERA, J.H.; TORRES, P.L. Farming of prawns and shrimps. Extension Manual 5. Iloilo, Philippines: SEAFDEC Aquaculture Department, 1983. 67p. (Extension Manual, 5).

ARULAMPALAM, P.; YUSOFF, F.M.; SHARIFF, M.; LAW, A.T. Water quality and bacterial population in a tropical marine cage culture. Aquaculture, v.29, p.617-624, 1998.

BALLESTER, E.L.; WASIELESKY, W.J.; CAVALLI, R.O.; SANTOS, M.H.S. Influência do biofilme no crescimento do camarão-rosa Farfantepenaeus paulensis em sistemas de berçário. In: SEMANA NACIONAL DE OCEANOGRAFIA, 14., Rio Grande, 2001. Anais. Rio Grande: Ed. Centro Acadêmico Livre de Oceanologia, 2001. 1 CDRom. p.63.

BENSCHENIEDER, K.; ROBINSON, R.J. A new spectrophotometric method for the determination of nitrite in seawater. Journal of Marine Research, v.11, p.87-96, 1952.

Table 2 - Mean $( \pm \mathrm{SD})$ percentile of the population of $F$. paulensis post-larvae cultured in cages or pens with weight over $0.36 \mathrm{~g}$ during the 31 day-long experimental period.

\begin{tabular}{lccccc}
\hline \multirow{2}{*}{ Treatment } & \multicolumn{5}{c}{ Days } \\
\cline { 2 - 6 } & 1 & 14 & 22 & 26 & 31 \\
\hline Pens & 0 & $50.6 \pm 12.05$ & $84.0 \pm 2.64$ & $93.0 \pm 2.00$ & $99.6 \pm 0.57$ \\
Cages & 0 & $53.6 \pm 11.15$ & $84.3 \pm 4.04$ & $92.6 \pm 1.52$ & $96.6 \pm 3.05$ \\
\hline
\end{tabular}

Sci. Agric. (Piracicaba, Braz.), v.61, n.3, p.332-335, May/June 2004 
DOLCI, D.; WASIELESKY, W.J. Seletividade de malha para o cultivo do camarão-rosa Penaeus paulensis em gaiolas e cercados. In: REUNIÃO ANUAL DO INSTITUTO DE PESCA, 7., São Paulo, 1998. Resumo. São Paulo: Instituto de Pesca, 1998. p.53.

OSTRENSKY, A.; PILCHOWSKI, R.W. Cultivos experimentais de camarões marinhos em tanques-rede no litoral paranaense In: SIMPÓSIO BRASILEIRO DE AQUICUlTURA, 12., Goiânia, 2002. Anais. Goiânia: Ed. Editora da UFG, 2002. p.256.

PAQUOTTE, P.; CHIM, L.; MARTIN, J.L.M.; LEMOS, E.; STERN, M.; TOSTA, G. Intensive culture of shrimp Penaeus vannamei in floating cages: zootechnical, economic and environmental aspects. Aquaculture, v.164, p.151-166, 1998.

PEÑA, R.; PROSPERO, O. Floating nursery cage for higher survival. Asian Aquaculture, v.6, p.6-8, 1984.

SANTOS, M.H.S.; DOMINGOS, J.A.; SANTOS, E.A.; WASIELESKY, W.J. Utilização de alimentos naturais não processados e ração comercial na engorda de juvenis do camarão-rosa Farfantepenaeus paulensis. In: SEMANA NACIONAL DE OCEANOGRAFIA, 12. , Rio de Janeiro, 1999. Resumo. Rio de Janeiro: Ed. UERJ, 1999. p.162-164.

SCARDUA, M.P. Utilização de alimentadores do tipo bandeja no cultivo de camarão rosa Penaeus paulensis (Pérez-Farfante, 1967) em tanques redes. Florianópolis: UFSC, 1998. 78p. (Dissertação -Mestrado)

SPECK, R.C.; CAVALLI, R.O.; MARCHIORI, M.A. Efeito da densidade de estocagem do camarão rosa Penaeus paulensis (PÉREZ-FARFANTE, 1967) em sistema de berçário. In: SIMPÓSIO BRASILEIRO SOBRE CULTIVO DE CAMARÃO, 4., João Pessoa, 1993. Anais. João Pessoa: MCR Aquacultura, 1993. p.369-383.

STRICKLAND, J.D.H.; PARSONS, T.R. A practical handbook of seawater analysis. Ottawa: Fishery Research Board Canada, 1972. 310p.

THOMPSON, F.L.; ABREU, P.C.; WASIELESKY, W.J. Importance of biofilm for water quality and nourishment in intensive shrimp culture. Aquaculture, v.203, p.263-278, 2002.
TSUZUKI, M.Y.; CAVALLI, R.O.; BIANCHINI, A. The effects of temperature, age, and acclimation to salinity on the survival of Farfantepenaeus paulensis postlarvae. Journal of the World Aquaculture Society, v.31, p.459-468, 2000.

UNESCO. Chemical methods for use in marine environmental monitoring. Paris: Intergovernamental Oceanographic Commission, 1983. (Manual and guides,12).

VINATEA, L.A. Princípios químicos da qualidade da água em aquicultura. Florianópolis: Editora da Universidade Federal de Santa Catarina, 1997. 166p.

WALFORD, J.; LAM, T.J. Floating hatchery and net cage culture of Penaeus indicus in the straits of shore, Singapore. Aquaculture, v.62, p.11-32, 1987.

WASIELESKY, W.J. Cultivo de juvenis do camarão-rosa Farfantepenaeus paulensis (Decapoda, Penaeidae) no estuário da Lagoa dos Patos: Efeitos de parâmetros ambientais e manejo de cultivo. Rio Grande: FURG, 2000. 199p. (Tese - Doutorado)

WASIELESKY, W.J.; CAVALLI, R.O.; DOLCI, D.; SILVA, T.M.A Crescimento do camarão-rosa Penaeus paulensis (Crustacea:Decapoda) cultivado em gaiolas e cercados, no estuário da Lagoa dos Patos. In: ENCONTRO SUL BRASILEIRO DE AQUACULTURA, 3., Ibirubá,1995. Anais. Porto Alegre: Ed. UFRGs, 1995. p.14-25.

ZOGBI, P.R. Efeito da taxa de arraçoamento no crescimento e sobrevivência do camarão-rosa Penaeus paulensis cultivado em gaiolas. Rio Grande: FURG, 1997. 33p. (Monografia -Graduação)

Received May 25, 2003

Accepted February 02, 2004 